Yeshiva University, Cardozo School of Law

LARC @ Cardozo Law

Articles

Faculty

1993

\title{
Transitional Constitutions
}

Arthur J. Jacobson

Benjamin N. Cardozo School of Law, ajacobsn@yu.edu

Follow this and additional works at: https://larc.cardozo.yu.edu/faculty-articles

Part of the Law Commons

\section{Recommended Citation}

Arthur J. Jacobson, Transitional Constitutions, 14 Cardozo Law Review 947 (1993).

Available at: https://larc.cardozo.yu.edu/faculty-articles/89

This Article is brought to you for free and open access by the Faculty at LARC @ Cardozo Law. It has been accepted for inclusion in Articles by an authorized administrator of LARC @ Cardozo Law. For more information, please contact larc@yu.edu. 


\title{
TRANSITIONAL CONSTITUTIONS
}

\author{
Arthur J. Jacobson*
}

Cass Sunstein urges the states of Eastern Europe to protect private property in their constitutions, and do it right away. ${ }^{1}$ If they do not, he warns, they will hobble the transition to market economies and disable their citizens from participating in democratic government. ${ }^{2}$

I dispute Professor Sunstein's thesis using two texts: Alfred Chandler's study of the requisites of industrial enterprise, Scale and Scope: The Dynamics of Industrial Capitalism, ${ }^{3}$ and Shakespeare's drama of constitutional transition, King Lear. ${ }^{4}$ Chandler's work casts doubt on Professor Sunstein's proposition that the exact constitutional arrangements for private property as we know it in the United States are essential to democracy and a market economy and questions whether private property is the core institution of development even in the United States. ${ }^{5}$ A reading of Shakespeare's King Lear suggests that Professor Sunstein, like Lear, overvalues the power of words to effect fundamental transformations in political conditions.

Echoing Shakespeare, I propose the idea of a "transitional constitution"-a constitution embodying, embracing, and propelling forward in the basic framework those political paradoxes which the great political forces are unable, for the moment, to resolve in permanent accommodations. A transitional constitution postpones the accommodation of political paradoxes using unstable principles instead for

- Max Freund Professor of Litigation and Advocacy, Benjamin N. Cardozo School of Law, Yeshiva University. Thanks to my colleagues, El Gates, Michael Herz, and John McGinnis, and to my wife, Peninah Petruck.

I Cass R. Sunstein, On Property and Constitutionalism, 14 Cardozo L. Rev. 907, 908 (1993).

2 Id.

3 Alfred D. Chandler, JR., SCale and Scope: The Dynamics of Industrial CapITALISM (1990).

4 William ShaKespeare, King Lear (Kenneth Muir, ed., Harvard Univ. Press 1963) [hereinafter KiNG LEAR].

5 By "private property," Professor Sunstein means the institution of private property as it exists today in western industrial democracies, where "individuals are entitled to decide how resources will be used." Sunstein, supra note 1 , at 911 n.19. By this definition, few individuals in the United States could be understood to own private property in the means of production, where in the great bulk of the Fortune 500 corporations, just as in government, offcers make management decisions, not "individuals." From the other side of the equation, many officers, both in government and in industry, treat offices like fiefdoms resembling property. 
carrying on in the absence of agreement on one or more elements of the basic framework.

The paradox Eastern Europeans must embrace in the first round of constitution making is that establishing capitalist property in the name of efficiency requires abolishing socialist property, despite broad expectations masses of citizens formed in it over the past two generations. $^{6}$ In order to transform their political economies, Eastern Europeans must undermine the institution of property in the name of the institution of property-destroy property in order to save it. It would be surprising (and possibly mistaken) if the new constitutions of Eastern Europe did not reflect and acknowledge this paradox. Hence, even if we knew that Eastern Europe was headed towards a private property regime much like our own (which I doubt), it might be appropriate for those nations to adopt transitional constitutions, exactly as we did in 1789.

\section{Property or "Organizational Capability"?}

Chandler's Scale and Scope speaks to Professor Sunstein's first point-that failing to protect private property in the new constitutions of Eastern Europe will impair the transition to market economies. Chandler proposes a core of the dynamics of industrial capitalism. He calls this core "the organizational capabilities of the enterprise as a unified whole."7 According to Chandler,

[t]hese organizational capabilities were the collective physical facilities and human skills as they were organized within the enterprise. They included the physical facilities in each of the many operating units-the factories, offices, laboratories-and the skills of the employees working in such units. ${ }^{8}$

Chandler compares three exemplary approaches to achieving the organizational capabilities for carrying on modern industrial capitalism: the United States, ${ }^{9}$ Great Britain, ${ }^{10}$ and West Germany. ${ }^{11}$

Chandler argues that in the United States the institutions in which organizational capability flourished were fully in place by World War I, when American "competitive managerial capitalism" was deploying teams of production and separating ownership of capi-

6 Almost four generations of citizens in the former Soviet Union were governed under socialist regimes.

7 Chandler, supra note 3, at 594.

8 Id.

9 Chandler terms this regime "competitive managerial capitalism." See id. at part II.

10 He terms this system "personal capitalism." See id. at part III.

11 He calls the third "cooperative managerial capitalism." See id. at part IV. 
tal from management of enterprise. ${ }^{12}$ Chandler's picture of the institutionalization of organizational capability in the United States bears little resemblance to the ordinary understanding of private property as Professor Sunstein employs it. "Personal capitalism" in Great Britain comes the closest of Chandler's models to a property conception of enterprise. But Chandler points out that the lingering of personal capitalism into our century hampered British capitalists from achieving as much organizational capability as their American and West German counterparts in the same period. ${ }^{13}$

Nothing in Chandler's work suggests that the American, British, and West German approaches exhaust the institutional possibilities for achieving organizational capability. One would be most interested, for example, to hear Chandler's view on Japan, which may be far more relevant to Eastern European conditions than our own system. ${ }^{14}$ Certainly, Eastern Europeans shopping for models would want to investigate the Japanese version of organizational capability closely, not only because it is successful, but also because it is even less bound to the usual private property conceptions than our own. At any rate, Chandler would almost certainly agree that the Eastern European political economies could yield new approaches to organizational capability-approaches about which we can know little in advance of their implementation. History, accident, and the peculiarities of the Eastern European situation and the creativity of her peoples will determine the exact form in which those nations achieve, or fail to achieve, the organizational capabilities necessary for modern industrial enterprise.

Take, as an example of the accommodations Eastern European regimes may have to make, Professor Sunstein's suggestion

that government should be [constitutionally] constrained from imposing special disabilities on private enterprises, that is, from taxing, regulating, or otherwise discouraging private entities from operating on equal terms with official organs. ${ }^{15}$

Like Japanese firms, many enterprises in these formerly socialist regimes undertook to provide health care, housing, schooling, and other services to the families of their workers. Should the new governments insist that these community structures be immediately abolished? It is easy to think of strong reasons not to. A regime might be morally

\footnotetext{
12 Id. at $47-49$.

13 Id. at 235-37.

14 Chandler's remarks on Japan in Scale and Scope are sparse and do not attempt to create a model. See id. at 616-17.

is Sunstein, supra note 1 , at 927.
} 
unprepared to tolerate the probable suffering which would result from such a restriction. A regime might acknowledge the political reality that employees of socialist enterprises are also voters. It might also wish to use old community structures to experiment with novel forms of organizational capability. Professor Sunstein would allow the state to treat public and private enterprises differently, so long as they are not "similarly situated." 16 Apart from the "hard interpretive questions" to which Professor Sunstein alludes" ("hard" is not the word; I prefer "mind-boggling"), the principle of nondiscrimination does not address the issue of whether a government ought to put public enterprises in a situation "justifying" different treatment in the first place. To say that different legal treatment of a bad situation is rational (such as affirmative action) does not lead to the conclusion that the government ought to create the situation. Furthermore, shifting attention from the desirability of the situation to the rationality of the government's legal treatment of it is not necessarily a step forward, however well-intentioned.

Undoubtedly Professor Sunstein would argue that "noneconomic" values are as important in democratic regimes as organizational capability. However, it may be necessary to sacrifice some degree of organizational capability to satisfy these other values. Chief among them in our society is personal autonomy. Professor Sunstein insists on tracing even this value through the right to property. ${ }^{18}$ But institutions of property are not the only ones that can support autonomy. Suppose, instead, we traced autonomy through federalism and simple ideas of administrative law. We could conceive of firms as agencies that administer a delegation of power from a central authority, provide these agencies with guaranties of independence, constrain their decision-making powers by some standard of review promulgated by the central authority, and so forth. ${ }^{19}$ In other words, we could construct as many of our property concepts as we wished

16 Id. Professor Sunstein's tolerance for different treatment flows logically from the principle of nondiscrimination.

17 Id.

18 Id. at 914-15. Professor Sunstein does not say whether autonomy, in his view, would ever conflict with the achievement of organizational capability. Chandler's study provides powerful evidence that it does.

19 See Gerald E. Frug, The Ideology of Bureaucracy in American Law, 97 HARv. L. REv. 1276 (1984) (discussing bureaucratic organizations in terms of corporate and administrative law). See also Arthur J. Jacobson, The Private Use of Public Authority: Sovereignty and Associations in the Common Law, 29 BUFF. L. REV. 599, 600 (1980) ("[t]he law of associations ... can properly be understood only as a distribution of sovereignty to private persons beyond the precincts of the state apparatus."). 
through administrative law and federalism. ${ }^{20}$ We need not mention "property" to achieve the benefits of autonomy, nor trace autonomy, as Professor Sunstein does, through the institutions of property alone. $^{21}$

The role of property in our original constitutional framework has been repeatedly contested, and I will not rehearse the debates. Even excluding Jefferson, the Framers differed in their views on the role of property in the Constitution, and those views were not always obvious. In Number 10 of The Federalist, ${ }^{22}$ Madison made the rights of property derivative from the "faculties of men." "The protection of these faculties," he wrote, "is the first object of government." $23 \mathrm{He}$ does not propose protection of the rights of property as the first object. Faction results because citizens own "different degrees and kinds of property," 24 and a principal task of government is to manage the clash of factions over the great interests of the republic. Property cannot be protected absolutely, only moderately in a shifting program of careful management. This is clearly not the language of constitutional right. ${ }^{25}$

Madison's realism about the political adjustments the institution of property requires in democratic society is even more appropriate today, when the "degrees and kinds" of property have become even more various. In a political economy dominated by teams of production and the separation of ownership of capital from management of enterprise, constitutional protection of property rights as Professor Sunstein proposes may have only symbolic significance. These symbols may be important in our tradition, but they need not play the same role in others.

Each state must battle out the clashes Madison described on its

20 In a sense, that is exactly how the high-medieval lawyers in our tradition arrived at the concept of property.

21 My colleague, Michael Herz, has suggested as another analogy, in light of my discussion of King Lear, that parents can give children lots of autonomy without necessarily giving them much property, or give them property without necessarily giving them much autonomy, as in King Lear.

22 The Federalist No. 10 (James Madison).

23 Id. at 131 (Benjamin F. Wright ed., 1961).

24 Id.

25 Here $I$ must leave aside the poverty of current American theories about property. Unfortunately, we must turn to a different tradition-Hegel's Philosophy of Right-to get a decent understanding of property in a modern political economy. He describes at least three strands in the institution of property-the abstract property of legal persons, family capital and the capital of corporations-and the distinct role each strand plays in the political economy of the modem state. See G.W.F. Hegel, Philosophy of RIGHT fiा 41-70, 170-72, 199 . 208, and 250-56 (T.M. Knox trans., 1952) (1942). Hegel rejects attaching a property idea to an office. See id. at $\lceil 277$. 
own. Each must come to its own solutions. If the states of Eastern Europe do not, if they bring in carpetbaggers to give them the best advice on the latest constitutional fashions, then they risk achieving only constitutional syncretism-common enough in our century-not real transformation. ${ }^{26}$ The Mayans in Chiapas practice their ancient religion under the watchful eyes of the parish priest, using Catholic rite as a secret code. Even if the priest is not aware, the parishioners know what the rite truly signifies. ${ }^{27}$ Would the Eastern Europeans be any different were they to adopt all the wonderful Sunsteinian constitutional provisions? They may adopt provisions very much like the ones Professor Sunstein proposes, if only because international financial institutions require it, or because they wish to express revulsion for the ancien regime. But the risk still remains that they will mean something quite different by the provisions, and Professor Sunstein, along with the rest of us, will not know that because we will not know, or care to know, the secret code.

\section{A Lesson in Transitional Constitutions}

It is probable that the states of Eastern Europe can not immediately resolve all their clashes of faction. They need, and I believe they can have, what I call a "transitional constitution." The second text which addresses this idea is King Lear. "Lear," in Scots, means instruction or lesson. ${ }^{28}$ This man learned a lesson-a lesson about the difficulties of constitutional transition. What Lear learned, at a terrible cost, was that he overvalued the power of words to effect fundamental political transformation.

Lear's first word in the play is "meantime." "Meantime we shall express our darker purpose." 29 The action of the play takes place "meantime," in a period of transition. Lear is handing over political authority to the husbands of his three daughters. ${ }^{30} \mathrm{He}$ wishes to divest himself of "rule, interest of territory, cares of state." " "['T]is our fast intent," he says, "To shake all cares and business from our age." ${ }^{32}$ But he would not give away the title of king. After he has

26 Professor Sunstein certainly does not recommend importing American constitutional provisions in haec verba into foreign circumstances. He does, however, wish to import what he regards as the functional requisites of our constitutional system, at least in the area of property.

27 See Franx Cancian, Economics ano Prestige in a Maya Community: The Religious Cargo System in Zinacantan 12 (1965).

286 THE OXFORD ENGLISH DICTIONARY 156 (3d ed. 1970).

29 KING LEAR, supra note 4, act I, sc. 1, line 36.

30 Cordelia thus needs to marry in order to get her share of the inheritance.

31 KING LEAR, supra note 4, act I, sc. 1, lines 49-50.

32 Id. at lines 38-39. 
given the kingdom to Albany and Cornwall, he says:

Only we shall retain

the name, and all the additions to a king;

the sway, revenue, execution of: the rest,

Beloved sons, be yours . . . . ${ }^{33}$

Lear thinks he can retain the name of king, and that giving away "the sway, revenue, execution of the rest" is of no import-just burdens as far as he is concerned. The play goes on to prove that Lear cannot do what he wishes. ${ }^{34}$ Retaining the title of king by itself means nothing. Nor does having "the sway, revenue, execution of the rest" mean anything without the title of king. Having one without the other leads to the very strife Lear sought to avoid by settling the succession prior to his death. In order to perfect a succession, Lear must give up both title of king and "the sway, revenue, execution of the rest."

Also, Lear must surrender them legitimately, according to the laws of succession. Lear violated these laws by holding an auction for his kingdom, the coin for which was his daughters' tokens of love. Lawlessly cutting Cordelia out of her inheritance invalidated the succession. Shakespeare does not mean to dispute the importance of love in establishing legitimacy. ${ }^{35}$ Lear's error was to look for professions of love, not love itself, in settling the succession. He overvalues words. What he says to Cordelia, when he casts her out, cannot be true:

Here I disclaim all my paternal care,

Propinquity and property of blood,

And as a stranger to my heart and me

Hold thee from this for ever. ${ }^{36}$

Lear's fate teaches that you cannot eliminate "[p]ropinquity and property of blood" quite so easily, certainly not by words of disclaimer alone.

33 Id. at lines 135-37.

34 And that he has not done what he said he wishes. My colleague, Professor Paul Shupack, points out that Lear doesn't even give up "the sway, revenue, execution of all the rest," since he banishes Kent immediately after effecting the transfer! See id. at lines 154-78.

35 The subplot of Gloucester, Edgar, and Edmund examines this issue with some care.

$36 \mathrm{Id}$. at lines 113-16. "Cordelia," of course, comes from the Latin for "heart." Cordelia, by the way, suffers from the same problem as her father: she too overvalues words (why not just give the old man the tokens he requires?). King Lear stands for an account of justice in which language is in just proportion with feeling. Lear and Cordelis suffer the punishment of those in whom language and feeling are out of whack. The Dean's December, Saul Bellow's study of the personal and political consequences of disproportion between language and feeling, is the story of his own Cordelia: Albert Corde. Bellow's Cordelia is also Albany-the husband of Goneril who puts the kingdom back in order. Corde, coincidentally, is dean at a scarcely fictionalized University of Chicago-Professor Sunstein's home institution. See SAUL Bellow, The Dean's December (1982). 
The lesson of King Lear is that the Eastern European regimes cannot get rid of their "[p]ropinquity and property of blood"-their socialist traditions-quite as easily as Professor Sunstein might wish. Must not some transition, some clashing of factions, be embodied in their constitutions? ${ }^{37}$ The constitutions the Eastern Europeans produce may not, initially, be to our liking, but they, not we, have to make them. If the new regimes unsettle expectations that millions of their citizens have built up under socialism, how can they expect to settle new expectations? What sort of lesson, what "lear," would they then be teaching?

\section{ReFlections on the ReVOlUtions IN THE UNITED States, Germany, aNd France}

The idea of a transitional constitution is not unusual, and certainly not foreign to our traditions. The United States has had two transitional constitutions: the Articles of Confederation and the Constitution of 1787. The Articles of Confederation was entirely transitional, in that the paradox expressed in it went to the entire frame of government: whether two sovereigns could coexist on a single territory - the paradox of federalism and the nature of national sovereignty. The Constitution of 1787 was partially transitional, in that its paradox-whether men own property or property owns men-affected only certain provisions, not the entire frame of government. Neither document resolved the conflict embodied in it. The paradox of the Articles of Confederation was resolved "peacefully" under the threat of external domination. The paradox of the Constitution of 1787 was resolved only by civil war and, effectively, by a third constitution-the Constitution of 1865-70.

There is no guaranty that ordinary, nonconstitutional politics will be able to peacefully resolve the paradoxes embodied in a transitional constitution, or that a second Madisonian constitutional moment will rescue the failures of ordinary politics without disintegration or violence. ${ }^{38}$ The idea of a transitional constitution does not require trust in ordinary politics or faith in a second Madis-

37 Professor Jon Elster agrees that "commitment to standing rules" may not be desirable given the rapid social and economic changes in Eastern Europe. See Jon Elster, Constitutionalism in Eastern Europe: An Introduction, 58 U. CHI. L. Rev. 447, 481 (1991).

38 I prefer the term "ordinary politics" to Bruce Ackerman's term "normal politics." See Bruce Ackerman, We the People: Foundations 171 (1991). The word "normal" implies that constitutional politics are "abnormal," hence "unhealthy," or "not according to norms." Certainly this is one position on constitutional politics, but not the only one. "Ordinary" contrasts with "extraordinary," without loading the normative dice against the "extraordinary politics" of foundational constitutional moments. 
onian moment. We have transitional constitutions not because we want them, but because we have no choice given our probable inability to resolve the clashes of factions completely in a single Madisonian moment.

By the same token, few constitutions that are in fact transitional set that forth in the document. The Grundgesetz-Basic Law-of the Federal Republic of Germany is one that does. The German parliament adopted it in 1949 as legislation (Gesetz), not as a constitution (Verfassung), with the specific intent that a true constitution must await the reunification of Germany. But the American Constitution of 1787 did not announce that it was transitional in the sense that the constitution as then written embodied a paradox in the basic framework. Article V's amending power permits, but does not require, a constitution of permanent transition. It is conceivable that the paradox embodied in the Constitution of 1787-whether men own property or property owns men-could have been resolved short of civil war and the Thirteenth Amendment. ${ }^{39}$ One could imagine the United States government "taking" the slaves as property for the public pur" pose of manumitting them, giving the Southern slaveowners "just compensation" for their property. Noxious as the institution of slavery is and was, no one doubted that owning slaves as property was lawful under the laws and Constitution of the United States and of the several states in which slaveowners had land. ${ }^{40}$ Had the Northern states agreed with the Southern states to "take" the slaves, free them, and compensate their owners with bonds (with a hefty percentage going to the slaves), then slaves would have been free and the South would have had capital for industrial development, all without formal resolution in a constitutional document. ${ }^{41}$ Would the Union have

39 The second tier of amendments-the Fourteenth in 1868 and the Fifteenth in $1870-$ certainly did more than resolve the paradox of the Constitution of 1787 . They dealt primarily with the paradox raised by the fact of insurrection over the first paradox: whether citizens of states are also citizens of the national sovereign, hence incapable of dissolving the constitution by the action of states as if it were an ordinary compact. The Fifteenth Amendment asserts the participation of former slaves as citizens of the national sovereign.

40 The Emancipation Proclamation, by these lights, was a "taking" without "just compensation." See Morris R. Cohen, Property and Sovereignty, 13 CORNELL L.Q. 8, 24-25 (1927) (Cohen, however, would not compensate the slave owners). So much for the force of constitutional provisions -in this case the Fifth Amendment-without the support of politics.

41 Henry Clay proposed a different idea-private purchase of slaves for the purpose of freeing them-attaching it, unfortunately, to a program of voluntary resettlement of emancipated slaves in Africa, Central America or the Western United States. See Paul D. Carrington, Butterfly Effects: The Possibilities of Law Teaching in a Democracy, 41 DukE L.J. 741, 770 (1992).

My colleague, Professor El Gates, informs me that Congressman Thatcher of Massachusetts proposed in January of 1800 that slavery might be abolished without injury to slave owners, and that an appropriation be made for that purpose. 6 ANNALS OF CONG., 232, 240 
been better off had ordinary politics come up with this "nonconstitutional" solution? ${ }^{42}$

On the other hand, it may be a mistake even to attempt to resolve certain foundational paradoxes through ordinary politics. The Federal Republic of Germany may be making just this mistake. During reunification, many voices in Germany called for a new constitution to replace the Grundgesetz, in recognition of the Madisonian moment made possible by the melding of two different social systems. The difficulties Germany is experiencing today may confirm the wisdom of this position.

The evil I am counselling against, and to which I believe Professor Sunstein's project is prey, is making constitutions that express ideal intellectual projects rather than real political solutions hammered by factions into constitutional traditions. Ideal intellectual projects are at best useless - distractions from the hard constitutional bargaining that factions often wish to avoid. At worst, they discredit the whole constitutional project by turning constitutions into mere "words on paper," or by offending the constitutional traditions of the nation that the promoters of the ideal intellectual project think they can neglect or avoid.

Constitutions must do more than merely set down the bargains of faction. They must express our best selves-but they must express our selves, not someone else's. It is always a danger sign when a constitution's ideal project drifts too far from the nexus of practical political action, as it did in France in the 1790s, and in Weimar in 1919. A new constitution cannot wipe out an old order by provisions. The ancien regime, the endless series of dependencies and hopes accumulated over generations, will not disappear even in a Madisonian moment. These hopes and dependencies have to be patiently worked through, in a practical politics informed by constitutional vision.

(1851). The House voted 85 to 1 that this section of a larger petition "receive no encouragement or countenance from this house." Id. at 244-45. Professor Gates also informs me that the New England Quakers, having manumitted their enslaved servants, made arrangements for compensating them for past services. The idea of compensation being due, not to the masters for loss of labor, but to the slaves for their years of unrequited toil and for the wrong done to both them and to their ancestors appears very early among the Quakers, according to Professor Gates. See William Burling, An Address to the Elders of the Church, in All SlaveKEEPERS 7 (Benjamin Lay ed., 1737) (1719).

42 Implicit in this political fantasy is a broader discussion of the relationship between labor and capital, a less pressing but equally pointed version of the governing paradox. Nonviolent resolution of the slavery version obviously would have affected the labor politics of the Gilded Age. On these matters see William E. Forbath, The Shaping of the American Labor Movement, 102 HARV. L. REV. 1109 (1989). On the equation of slavery with labor of any sort, see Plato, The Statesman (J.B. Skemp trans., 1952). 